UDK: $37.031: 316.774$

Prethodno saopštenje

Primljeno: 1.4.2018.

Revidirana verzija: 24.6.2018.

Odobreno za štampu: 25.6.2018.

\title{
MEDIJSKO OBRAZOVANJE I PERCEPCIJA RODNIH STEREOTIPA U MEDIJIMA
}

DOI: https://doi.org/10.46630/gped.1.2018.07

\author{
Tatjana Đukić1 \\ Univerzitet u Nišu, Filozofski fakultet, Departman za komunikologiju \\ i novinarstvo, doktorandkinja \\ Dušan Aleksić \\ Univerzitet u Nišu, Filozofski fakultet, Departman za komunikologiju \\ i novinarstvo
}

\begin{abstract}
Apstrakt: U radu autori se bave ispitivanjem percepcije rodnih stereotipa u medijima kod studenata koji su pohađali programe medijske pismenosti, te kompariranjem sa studentima koji to nisu. Cilj istraživanja bio je ispitati da li postoji razlika u percepciji rodnih stereotipa u medijima između ove dve grupe ispitanika. Primenjena metodološka tehnika za prikupljanje podataka bila je anketa, a uzorak su činili studenti Univerziteta u Nišu. Rezultati sprovedenog istraživanja pokazali su da statistički značajna razlika u percepciji rodnih stereotipa u medijima kod studenata koji su pohađali predmete koji tretiraju medijsku pismenost i onih koji to nisu, postoji jedino kod internalizacije rodnih stereotipa, odnosno da između ove dve grupe ispitanika postoji značajna razlika u stavu da mediji utiču na usvajanje rodnih uloga. Imajući u vidu rezultate istraživanja, kao i prethodne studije koje pokazuju da je kratka izloženost medijskoj pismenosti nedovoljna da izazove kontrareakciju dominantnog društvenog pritiska, preporuka je uspostavljanje sistemskog multimedijalnog opismenjavanja, i to u ranom osnovnoškolskom uzrastu, usled nezaustavljivog usložnjavanja informaciono-komunikacionog sistema.
\end{abstract}

Ključne reči: medijsko obrazovanje, studenti, rod, stereotipi, mediji.

\section{Novi mediji: šuma simbola}

U savremenom društvu mediji i nove medijske tehnologije nezaustavljivo prodiru u sve sfere društva, preuzimajući sve dominantniju ulogu među faktorima koji na njega utiču. Brojni su načini na koje mediji deluju na konkretnu zajednicu, a koji su uslovljeni tržišnim, političkim, ideološkim i drugim uticajima. Moć novih medija ojačana je tehnološkim inovacijama, i popularizaijom interneta, što označava poče-

\footnotetext{
${ }^{1}$ tatjana.aiki@gmail.com
} 
tak perioda nove komunikacijske ere. Na taj način, prostor sukoba u borbi za kontrolom simboličkog polja širi se na nove komunikacijske kanale, sa tradicionalnih medija, u prostor na mreži, čiji je uticaj danas mnogo veći, posebno među mlađom populacijom. U poređenju sa ranijim društveno-istorijskim periodima, usled ekspanzije, usložnjavanja i usavršavanja kanala masovnog komuniciranja, i socijalizatorska uloga medija nemerljivo raste.

Kako je Daglas Kelner (Douglas Kellner) još 1998. godine u tekstu „Višestruka pismenost i kritička pedagogija u multikulturnom društvu“ upozoravao „savremenu kulturu obeležava proliferacija kulturnih mašina koje generišu širok spektar štampanih, zvučnih, ekoloških i raznovrsnih estetskih artefakata u okviru kojih lutamo, pokušavajući da prođemo kroz ovu šumu simbola" (Kellner, 1998: 10). Ovakva „šuma simbola“, odnosno simbolička stvarnost ono je što karakteriše moderno medijatizovano društvo, posredovano novim oblicima odašiljanja i primanja poruka, koje su takođe predimenzionirane. Naime, medijske poruke karakteristične za nove medije podrazumevaju hipertekstualnost, multimedijalnost, te mogućnost interagovanja sa korisnicima. Novo medijsko doba, dakle, karakteriše i rekoncepcija medijskog sadržaja, jer publika više nije pasivna, kako je često označavana u tradicionalističkom pristupu proučavanja medija, već pojedinac može preuzeti i ulogu komunikatora, diseminirati poruke, i na taj način uticati na javno mnjenje.

Međutim, iako novi mediji demokratizuju medijsku sferu, u smislu pristupa korisnika, $u$ današnjem informaciono-komunikacionom sistemu suptilne manipulativne tehnike, i oblikovanje ljudske svesti jednostavnije je u poređenju sa bilo kojim istorijskim periodom. Poruke se ne uskraćuju publici cenzurom, već upravo neograničenom ponudom istovetnog, u čijem vrtlogu se one važne gube. U sveopštem „tuširanju informacijama“ prosečni korisnik medijskih sadržaja zaboravlja da medijski posredovane poruke, koncipirane da odaju utisak da prezentuju realnu sliku stvarnosti, zapravo predstavljaju reprezente simboličke stvarnosti, odnosno manifestaciju određenih značenja. Terminom medijska reprezentacija upravo se potencira da medijske predstave nisu odrazi sveta, već da, kako Nalević ističe, „mediji za određenu publiku re-kreiraju predstavu, re-prezentuju objekat ili proces u njegovom odsustvu. To znači da mediji stvarnost prepoznaju, imenuju, simbolički fiksiraju i daju joj značenje. Na taj način, svaka medijska rekonstrukcija mora biti shvaćena kao politički događaj jer ona reprezentuje neki interes koji se tiče kontrole i moći" (Nalević, 2008: 5).

Prema mišljenju Ninković-Slavnić, reprezentacija se odvija kroz dve vrste sistema: ,prvi, koji svet organizuje u smislene šeme i kategorije; i drugi, sistem znakova kojima se kategorije dele sa drugim članovima društva. Kroz reprezentaciju se kontinuirani kompleksni svet uređuje time što se određene stvari, odnosno kad je reč o ljudima osobine selektuju i kategorizuju, obeležavaju i komuniciraju“" (NinkovićSlavnić, 2011: 16). 


\section{Rodna reprezentacija u medijima: Čitanje i učitavanje}

Mediji konstituišu ideale, definišu poželjne forme mišljenja i ponašanja, izgledanja i bitisanja, a te konstrukcije uvek su, kako je već navedeno, ideološki obojene. U kontekstu predstavljanja roda u medijima, ideološke note primetne su u reprezentaciji ograničenog broja uloga, dominacije i submisivnosti, i karakternih crta koje se tradicionalno pripisuju muškarcu, odnosno ženi, te izraženoj ženskoj seksualnosti, i muškoj moći.

Kada je medijska reprezentacija u pitanju, važno je istaći da se u javnom prostoru rod upravo konstituiše kao direktan proizvod procesa reprezentacije koji se vrši posredstvom medija. A kako Marija Vujović objašnjava, ,reprezentacijom se naglašava da je nešto preoblikovano, kodirano teorijskim, tekstualnim ili likovnim terminima, nešto posve različito od svog društvenog postojanja. Reprezentacija kao konstrukcija stvarnosti uvek podrazumeva postojanje ideja, interesa, namera, ideologije“"(Vujović, 2016: 10).

Rodnu reprezentaciju kao klasičnu stereotipizaciju, koja može voditi različitim vidovima diskriminacije, nije uvek jednostavno detektovati, usled naučenosti kroz proces socijalizacije i obrazovanja, da su načini predstavljanja žena i muškaraca u medijima zapravo odgovarajući realnosti, te utemeljeni u prirodi, odnosno biološki determinisani. Dodatnu konfuziju u detektovanju propagirane potlačenosti žena i ideologije patrijarhata u medijima, izaziva i medijsko ohrabrivanje žena da budu privlačne, te da „oslobode svoju seksualnost“. Ipak, submisivnost se u ovom slučaju ogleda u činjenici da žene i dalje zavise od patrijarhalno definisanog suda.

Kako bi objasnili način na koji rodna reprezentacija u medijima utiče na ponašanje i razmišljanje žena, Basi i Bandura (Kay Bussey, Albert Bandura) koriste socijalno kognitivnu teoriju. Ova teorija ističe važnost "modelovanja" - "jednog od najubedljivijih i najjačih načina za prenošenje vrednosti, stavova, modela razmišljanja i ponašanja" (Bussey i Bandura, 1999: 16). Naime, kako autori ističu, veliki broj informacija povezanih sa rodom dolazi od modela iz neposredne okoline, kao što su roditelji, vršnjaci, značajne osobe u društvenom, obrazovnom i radnom okruženju. Međutim, sveobuhvatno modeliranje rodnih uloga i ponašanja vrši se i posredstvom medija masovnog komuniciranja, kada medijski posredovani likovi postaju modeli.

Oni akteri i verzije sveta kojja je u skladu sa dominantnom ideologijom nosilaca moći u društvu sveprisutni su u medijskom diskursu. Na taj način, koristeći verbalne i vizualne simboličke odrednice, stižu do medijske publike, koja te sadržaje često prihvata nekritički, dozvoljavajući da njena pažnja bude usmerena. Prikazivanje stvarnosti jeste moguće iz različitih perspektiva, ali se u medijima uvek daje prednost onoj vrsti predstavljanja koje je u skladu sa interesima vodeće elite. Teorija dnevnog reda (agenda setting theory ${ }^{2}$ ) predstavlja pozicioniranje, odnosno isticanje određenih odgovarajućih medijskih sadržaja, to jest tema, bilo da je reč o tradicionalnim, ili novim medijima. S obzirom na to da se na taj način favorizuju određene teme, lica, događaji i vrednosti, oni zauzimaju dominantno mesto u percepciji korisnika medijskih informacija.

\footnotetext{
${ }^{2}$ Temelje teorije dnevnog reda postavio je Volter Lipman (Walter Lippman) 1922. godine, a dalje su je razvili i dopunili Mekomb (McCombs) i Šo (Shaw).
} 
Džordž Gerbner (George Gerbner), usvajanje medijsko propagiranih vrednosti, objašnjava kultivacionom teorijom, koja se fokusira na simboličko okruženje u medijima koje utiče na stavove i ponašanja. Naime, prema teoriji kultivacije izloženost medijskim porukama izaziva da pojedinci postepeno „kultivišu“ uverenja o svetu, koja se podudaraju sa porukama koje primaju iz medija (Gerbner i ostali, 1994). Sa tim u vezi, Gerbner tvrdi da mediji ,socijalizuju većinu ljudi u standardizovane uloge i ponašanja“"(Gerbner, 1976: 175).

Međutim, Gerbnerova teorija bila je kritikovana sa više aspekta. Jedan od ra-

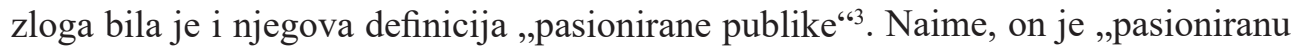
publiku" $i$ onu koja to nije razlikovao u odnosu na broj časova koje provedu gledajući televiziju dnevno. U „pasionirane“ svrstavao je one koji to čine više od četiri sata dnevno, i tvrdio da su oni podložniji uticaju medijskih poruka. Stoga, ova je teorija potpuno zanemarivala značaj individualnih razlika, podrazumevala izuzetnu pasivnost publike i uzimala u obzir vrlo malo uticaja iskustava iz realnog sveta, kada je u pitanju prihvatanje uramljenog medijskog sveta kao „realnog.“ Gerbner se “nije bavio načinom na koji su ljudi birali poruke kojima su izloženi, niti kako su obrađivali informacije u tim porukama, niti kakve su efekte imale određene poruke na ljude tokom izlaganja ili odmah nakon toga" (Potter, 2014: 1016). Gerbner se isključivo bavio uticajem koji poruke vrše na javnost koja je bila izložena medijskim porukama u svakodnevnom životu, u odnosu na trajanje njihove izloženosti.

Danas, kada mediji prožimaju sve sfere javnog, ali i privatnog života, kada su tradicionalni mediji nadgrađeni, a novi konstruisani da mogu da stanu u džepove, kada je bez njihovog korišćenja skoro nemoguće zamisliti uspešno obavljanje svakodnevnih aktivnosti, jasna je njihova moć, i nužnost kritičkog preispitivanja svih koncepata koje kontinuirano konstruišu i nameću.

\section{Ključ kritičnosti: Multimedijalna pismenost}

Dominacija medija u svim segmentima društvenog i individualnog, zahteva razvoj nove multimedijalne pismenosti koja, kako Kelner ističe, skenira, interaguje, povezuje i ukršta, i organizuje novo multimedijalno obrazovno okruženje. Sa tim u vezi, on objašnjava i da postmoderna pedagogija, nasuprot modernoj koja je bila fokusirana na štampanu kulturu, podrazumeva razvijanje višestruke pismenosti, kritičko analiziranje, raščlanjivanje i angažovanje mnoštva kulturoloških oblika, od kojih su neki proizvodi novih tehnologija (Kellner, 1998).

Osim linijskih kognitivnih veština, koje su neophodne za čitanje tradicionalnih, štampanih medija, i koje se u obrazovnom sistemu potencira, neophodan je razvoj nove multimedijalne pismenosti, koja, kako Kelner (isto) navodi, podrazumeva čitanje hiperteksta, koji je često višedimenzionalan i podrazumeva povezivanje slika, grafike, tekstova i ponekad audio i video materijala. Definisana ovako, multimedijalna pismenost takođe podrazumeva kritiči odnos prema kompleksnom i višeslojnom sajber-svetu, kao i njegovo kritičko povezivanje sa realnim.

\footnotetext{
3 "Heavy viewers"
} 
Džejms Poter, zagovornik kognitivne teorije medijske pismenosti, ističe važnost medijske pismenosti u razvoju kritičkih pozicija u kognitivnom razvoju. Medijska pismenost ,pomaže pojedincima da promene svoje ponašanje, kako bi ih osnažila da koriste medije, kako mediji ne bi koristili njih“ (Potter, 2004: 271).

Intervencije i inovacije u obrazovnom sistemu, kao što su uvođenje programa medijske pismenosti, mogu biti polazna osnova za razvoj kritičkog odnosa prema medijskim stereotipima o rodu koje mediji prikazuju. Upravo je cilj medijske pismenosti da stvori aktivne interpretatore medijskih poruka, sa kritičkom distancom prema medijskim sadržajima, umesto pasivnih recipijenta, kako ih je Gerbner definisao, koji samo površno konzumiraju medijske produkte.

Ipak, studije koje ispituju kako kritičko mišljenje o rodnim stereotipima u medijima kroz medijsku pismenost može doprineti dekonstrukciji rodnih stereotipa, te sprečavanju internalizacije seksualizovanih i nametnutih ideala lepote, i poželjnih vrednosti, pokazuju da je kratka izloženost medijskoj pismenosti nedovoljna da izazove kontrareakciju dominantnog društvenog pritiska, kada su stereotipni ideali u masovnoj kulturi u pitanju. Naime, zaključak studije koja je upoređivala efikasnost programa medijske pismenosti jeste da iako izloženost medijskoj pismenosti povećava „svest“, ne smanjuje „,internalizaciju“ stereotipnih ideala lepote (Irving \& Berel, 2001).

\section{Metodologija}

Predmet istraživanja je ispitivanje percepcije rodnih stereotipa u medijima kod studenata koji su pohađali programe medijske pismenosti, te kompariranje sa studentima koji nisu, dok je cilj istraživanja ispitati da li postoji razlika u percepciji rodnih stereotipa u medijima između ove dve grupe.

Primenjena metodološka tehnika za prikupljanje podataka jeste anketa, koja je sadržala 13 pitanja, sprovedena na uzorku od 100 ispitanika, studenata Univerziteta u Nišu, čija je struktura prema polu, godinama starosti, i načinu informisanja prikazana u tabelama 1, 2 i 3, dok je u tabeli 4 predstavljena struktura uzorka prema medijskom obrazovanju.

Tabela 1. Struktura uzorka prema polu

\begin{tabular}{lll}
\hline Pol & Broj ispitanika & Procenat \\
\hline Muški & 28 & $28 \%$ \\
Ženski & 72 & $72 \%$ \\
\hline
\end{tabular}

Tabela 2. Struktura uzorka prema godinama starosti

\begin{tabular}{lll}
\hline Starost & Broj ispitanika & Procenat \\
\hline Mlađi/mlađa od 20 & 10 & $10 \%$ \\
Od 21 do 25 godina & 54 & $54 \%$ \\
Stariji/starija od 26 & 36 & $36 \%$ \\
\hline
\end{tabular}


Tabela 3. Struktura uzorka prema načinu informisanja

\begin{tabular}{lll}
\hline Medij & Broj ispitanika & Procenat \\
\hline Televizija & 14 & $14 \%$ \\
Radio & 3 & $3 \%$ \\
Štampa & 2 & $2 \%$ \\
Onlajn medijski portali & 34 & $34 \%$ \\
Aplikacije medijskih portala & 9 & $9 \%$ \\
Društvene mreže & 38 & $38 \%$ \\
\hline
\end{tabular}

Tabela 4. Struktura uzorka prema medijskom obrazovanju

\begin{tabular}{lll}
\hline Medijsko obrazovanje & Broj ispitanika & Procenat \\
\hline $\begin{array}{l}\text { Pohađao/la predmete koji se tiču } \\
\text { medijske pismenosti }\end{array}$ & 41 & $41 \%$ \\
$\begin{array}{l}\text { Nije pohađao/la predmete koji se tiču } \\
\text { medijske pismenosti }\end{array}$ & $59 \%$ \\
\hline
\end{tabular}

\subsection{Plan statističke obrade podataka}

Za unos podataka i njihovu analizu korišćen je program SPSS for Windows, verzija 15.0. Primenjeni su statistički postupci: deskriptivna statistika (frekvenca, kros-tabulacije i hi-kvadrat test).

\section{Rezultati istraživanja}

Sagledavanje percepcije rodnih stereotipa u medijima studenata započeto je ispitivanjem njihovog uopštenijeg stava prema medijima, odnosno ispitivanjem njihovog odnosa prema realnosti sadržaja u medijima masovnog komuniciranja.

Tabela 5. Mediji predstavljaju realnu sliku stvarnosti.

\begin{tabular}{lllll}
\hline Medijsko obrazovanje & Saglasan & Nisam siguran & Nisam saglasan & Ukupno \\
\hline $\begin{array}{l}\text { Pohađao/la predmete koji se tiču } \\
\text { medijske pismenosti }\end{array}$ & 1 & 8 & 32 & 41 \\
$\begin{array}{l}\text { Nije pohađao/la predmete koji } \\
\text { se tiču medijske pismenosti }\end{array}$ & 11 & 45 & 59 \\
\begin{tabular}{l} 
Ukupno \\
\hline
\end{tabular} & 4 & 19 & 77 & 100 \\
\hline
\end{tabular}

Tabela 5 pokazuje da $77 \%$ anketiranih studenata smatra da mediji ne predstavljaju realnu sliku stvarnosti, $19 \%$ nije sigurno, dok $4 \%$ smatra da mediji realno oslikavaju stvarnost.

Primenom Hi-kvadrat testa (Chi-Square Test) nije utvrđena statistički značajna razlika između studenata koji su pohađali programe medijskog obrazovanja i onih 
koji to nisu, u odnosu na stav da mediji predstavljaju realnu sliku stvarnosti (Pearson Chi-Square (Asymp. Sig $(2$-sided $)=0,801)$ ). Ovakvi iskazi obe grupe studenata ne čude, imajući u vidu da više od $60 \%$ ispitanika čine osobe do 25 godina, koje predstavljaju onu kategoriju u društvu koja je intenzivno kroz veći period odrastanja upotrebljavala razna sredstva masovnog komuniciranja, te poseduje određenu svest o njihovom funkcionisanju.

Tabela 6. Žene su u medijima stereotipno predstavljene.

\begin{tabular}{lllll}
\hline Medijsko obrazovanje & Saglasan & Nisam siguran & $\begin{array}{l}\text { Nisam } \\
\text { saglasan }\end{array}$ & Ukupno \\
\hline $\begin{array}{l}\text { Pohađao/la predmete koji se tiču } \\
\text { medijske pismenosti }\end{array}$ & 27 & 7 & 7 & 41 \\
$\begin{array}{l}\text { Nije pohađao/la predmete koji se tiču } \\
\text { medijske pismenosti }\end{array}$ & 30 & 19 & 10 & 59 \\
Ukupno & 57 & 26 & 17 & 100 \\
\hline
\end{tabular}

U tabeli 6 ilustrovani su sledeći podaci: 57\% anketiranih studenata smatra da su žene u medijima stereotipno predstavljene, 26\% nije sigurno, dok 17\% nije saglasno sa ovom tvrdnjom.

Primenom Hi-kvadrat testa (Chi-Square Test) nije utvrđena statistički značajna razlika između studenata koji su pohađali programe medijskog obrazovanja i onih koji to nisu, u odnosu na stav da su žene u medijima stereotipno predstavljene (Pearson Chi-Square (Asymp. Sig (2-sided) =0,214)).

Tabela 7. Muškarci su u medijima stereotipno predstavljeni.

\begin{tabular}{lllll}
\hline Medijsko obrazovanje & Saglasan & Nisam siguran & $\begin{array}{l}\text { Nisam } \\
\text { saglasan }\end{array}$ & Ukupno \\
\hline $\begin{array}{l}\text { Pohađao/la predmete koji se tiču medijske } \\
\text { pismenosti }\end{array}$ & 20 & 14 & 7 & 41 \\
$\begin{array}{l}\text { Nije pohađao/la predmete koji se tiču } \\
\text { medijske pismenosti }\end{array}$ & 22 & 22 & 15 & 59 \\
Ukupno & 42 & 36 & 22 & 100 \\
\hline
\end{tabular}

U tabeli 7 prikazan je stepen saglasnosti anketiranih studenata sa tvrdnjom da su muškarci u medijima stereotipno predstavljeni. $42 \%$ studenata saglasno je sa tvrdnjom, $36 \%$ nije sigurno, dok $22 \%$ ispitanika smatra da muškarci u medijima nisu stereotipno predstavljeni. Stav nesigurnosti je u ovom slučaju za $10 \%$ učestaliji nego kod stereotipizacije žena.

Primenom Hi-kvadrat testa (Chi-Square Test) nije utvrđena statistički značajna razlika između studenata koji su pohađali programe medijskog obrazovanja i onih koji to nisu, u odnosu na stav da su muškarci u medijima stereotipno predstavljeni $($ Pearson Chi-Square $($ Asymp. Sig $(2$-sided $)=0,415))$. 
Tabela 8. Mediji promovišu potpuno prirodne ženske uloge.

\begin{tabular}{lllll}
\hline Medijsko obrazovanje & Saglasan & Nisam siguran & Nisam saglasan & Ukupno \\
\hline $\begin{array}{l}\text { Pohađao/la predmete koji se tiču } \\
\text { medijske pismenosti }\end{array}$ & 5 & 11 & 25 & 41 \\
$\begin{array}{l}\text { Nije pohađao/la predmete koji se tiču } \\
\text { medijske pismenosti }\end{array}$ & 8 & 12 & 39 & 59 \\
\begin{tabular}{l} 
Ukupno \\
\hline
\end{tabular} & 13 & 23 & 64 & 100 \\
\hline
\end{tabular}

Tabela 8 pokazuje da $64 \%$ ispitanika nije saglasno sa tvrdnjom da mediji promovišu potpuno prirodne ženske uloge, $23 \%$ nije sigurno, dok je $13 \%$ saglasno sa tvrdnjom.

Primenom Hi-kvadrat testa (Chi-Square Test) nije utvrđena statistički značajna razlika između studenata koji su pohađali programe medijskog obrazovanja i onih koji to nisu, kada je u pitanju stav da mediji promovišu potpuno prirodne ženske uloge (Pearson Chi-Square (Asymp. Sig $(2$-sided $)=0,749)$ ).

Tabela 9. Mediji promovišu potpuno prirodne muške uloge.

\begin{tabular}{|c|c|c|c|c|}
\hline Medijsko obrazovanje & Saglasan & Nisam siguran & Nisam saglasan & Ukupno \\
\hline $\begin{array}{l}\text { Pohađao/la predmete koji se tiču } \\
\text { medijske pismenosti }\end{array}$ & 5 & 13 & 23 & 41 \\
\hline $\begin{array}{l}\text { Nije pohađao/la predmete koji se tiču } \\
\text { medijske pismenosti }\end{array}$ & 11 & 18 & 30 & 59 \\
\hline Ukupno & 16 & 31 & 53 & 100 \\
\hline
\end{tabular}

U tabeli 9 ilustrovani su podaci o stepenu saglasnosti anketiranih studenata sa tvrdnjom da mediji promovišu potpuno prirodne muške uloge. 53\% studenata nije saglasno sa tvrdnjom, $31 \%$ nije sigurno, dok $16 \%$ smatra da mediji promovišu potpuno prirodne muške uloge. Nesigurnost u vezi sa „prirodnim ulogama“ muškaraca takođe je veća nego kod ,prirodnih uloga“ žena.

Primenom Hi-kvadrat testa (Chi-Square Test) nije utvrđena statistički značajna razlika između studenata koji su pohađali programe medijskog obrazovanja i onih koji to nisu, u odnosu na stav da mediji promovišu potpuno prirodne muške uloge $($ Pearson Chi-Square $($ Asymp. Sig $(2$-sided $)=0,682))$.

Tabela 10. Žene su češće objektivizirane u medijima.

\begin{tabular}{lllll}
\hline Medijsko obrazovanje & Saglasan & Nisam siguran & Nisam saglasan & Ukupno \\
\hline $\begin{array}{l}\text { Pohađao/la predmete koji se tiču } \\
\text { medijske pismenosti }\end{array}$ & 28 & 4 & 9 & 41 \\
$\begin{array}{l}\text { Nije pohađao/la predmete koji se tiču } \\
\text { medijske pismenosti }\end{array}$ & 35 & 16 & 8 & 59 \\
\begin{tabular}{l} 
Ukupno \\
\hline
\end{tabular} & 63 & 20 & 17 & 100 \\
\hline
\end{tabular}

Tabela 10 ilustruje da 63\% ispitanika smatra da su žene češće objektivizirane u medijima, 20\% ispitanika nije sigurno, dok $17 \%$ smatra suprotno. 
Primenom Hi-kvadrat testa (Chi-Square Test) nije utvrđena statistički značajna razlika između studenata koji su pohađali programe medijskog obrazovanja i onih koji to nisu, u odnosu na stav da su žene češće objektivizirane u medijima (Pearson Chi-Square (Asymp. Sig (2-sided) =0,084)).

Tabela 11. U medijima češće možemo videti muškarce kao eksperte.

\begin{tabular}{lllll}
\hline Medijsko obrazovanje & Saglasan & Nisam siguran & $\begin{array}{l}\text { Nisam } \\
\text { saglasan }\end{array}$ & Ukupno \\
\hline $\begin{array}{l}\text { Pohađao/pohađala predmete koji se tiču } \\
\text { medijske pismenosti }\end{array}$ & 32 & 3 & 6 & 41 \\
$\begin{array}{l}\text { Nije pohađao/pohađala predmete koji se } \\
\text { tiču medijske pismenosti }\end{array}$ & 40 & 9 & 10 & 59 \\
Ukupno & 72 & 9 & 16 & 100 \\
\hline
\end{tabular}

Tabela 11 pokazuje stepen saglasnosti anketiranih sa tvrdnjom da u medijima češće možemo videti muškarce kao eksperte, gde je 72\% ispitanika saglasno, 9\% nije sigurno, i 16\% nije saglasno sa ovim zapažanjem.

Primenom Hi-kvadrat testa (Chi-Square Test) nije utvrđena statistički značajna razlika između studenata koji su pohađali programe medijskog obrazovanja i onih koji to nisu, u odnosu na percepciju da u medijima češće možemo videti muškarce kao eksperte (Pearson Chi-Square (Asymp. Sig $(2$-sided $)=0,427)$ ).

Tabela 12. Prepoznajem seksizam u medijima.

\begin{tabular}{lllll}
\hline Medijsko obrazovanje & Saglasan & Nisam siguran & $\begin{array}{l}\text { Nisam } \\
\text { saglasan }\end{array}$ & Ukupno \\
\hline $\begin{array}{l}\text { Pohađao/pohađala predmete koji se tiču } \\
\text { medijske pismenosti }\end{array}$ & 33 & 4 & 4 & 41 \\
$\begin{array}{l}\text { Nije pohađao/pohađala predmete koji se tiču } \\
\text { medijske pismenosti }\end{array}$ & 41 & 15 & 3 & 59 \\
Ukupno & 74 & 19 & 7 & 100 \\
\hline
\end{tabular}

Tabela 12 ilustruje samoprocenu anketiranih o prepoznavaju seksizma u medijima, odnosno pokazuje da $74 \%$ ispitanika smatra da prepoznaje seksizam u medijima, $19 \%$ nije sigurno, dok $7 \%$ smatra da ga ne prepoznaje.

Primenom Hi-kvadrat testa (Chi-Square Test) nije utvrđena statistički značajna razlika između studenata koji su pohađali programe medijskog obrazovanja i onih koji to nisu, u odnosu na prepoznavanje seksizma u medijima (Pearson Chi-Square (Asymp. Sig $(2$-sided $)=0,118)$ ).

Tabela 13. Mediji utiču na usvajanje rodnih uloga.

\begin{tabular}{lllll}
\hline Medijsko obrazovanje & Saglasan & Nisam siguran & Nisam saglasan & Ukupno \\
\hline $\begin{array}{l}\text { Pohađao/pohađala predmete koji se } \\
\text { tiču medijske pismenosti }\end{array}$ & 32 & 6 & 3 & 41
\end{tabular}




\begin{tabular}{lllll}
$\begin{array}{l}\text { Nije pohađao/pohađala predmete koji } \\
\text { se tiču medijske pismenosti }\end{array}$ & 33 & 24 & 2 & 59 \\
Ukupno & 65 & 30 & 5 & 100 \\
\hline
\end{tabular}

Tabela 13 pokazuje stepen saglasnosti anketiranih sa stavom da mediji utiču na usvajanje rodnih uloga. $65 \%$ studenata saglasno je sa ovom tvrdnjom, $30 \%$ nije sigurno, dok 5\% nije saglasno.

Primenom Hi-kvadrat testa (Chi-Square Test) utvrđena je statistički značajna razlika između studenata koji su pohađali programe medijskog obrazovanja i onih koji to nisu, u odnosu na stav da mediji utiču na usvajanje rodnih uloga (Pearson Chi-Square (Asymp. Sig $(2$-sided $)=0,018)$ ).

\section{Zaključak}

Razvoj novih medijskih tehnologija i interneta nesumnjivo su uticali na to na koji način percipiramo medijske sadržaje. Mladi, koji odrastaju uz obilje kanala komuniciranja, čiji broj nezaustavljivo raste, i koji ih vešto upotrebljavaju u svakodnevnom životu, imaju izgrađenu svest o medijskim uticajima. Zbog toga, ne čudi činjenica da među studentima koji su pohađali programe koji tretiraju medijsku pismenost, i onih koji to nisu, ne postoje značajne razlike u vezi sa saglasnošću sa tvrdnjom da mediji ne predstavljaju realnu sliku stvarnosti. Rezultati sprovedene ankete pokazuju i da, kada su rodni stereotipi u pitanju, ne postoje značajne razlike u njihovom percipiranju. Anketirani studenti uglavnom su saglasni da su u medijima i žene i muškarci stereotipno predstavljeni, međutim, nesigurnost se u većoj meri javlja kod saglasnosti sa tvrdnjom o medijskoj stereotipizaciji muškaraca. Kada je u pitanju odnos prema ,prirodnim“ muškim i ženskim ulogama, anketirani studenti prepoznaju prikrivenu stereotipizaciju, tipičnu za medijsko uramljivanje određenih grupa, te svest da rod jeste društveno i medijski konstruisana kategorija. Obe grupe anketiranih studenata primećuju da se u ulozi eksperta u medijima u većem broju slučajeva pojavljuju muškarci, kao i da su žene češće objektivizirane, i predstavljene kao objekat seksualne pažnje. Sa tim u vezi, većina ispitanika smatra da su sposobni da detektuju seksističke konsturukte u medijskom prostoru.

Jedina značajna statistička razlika utvrđena anketom o percipiranju rodnih stereotipa u medijima kod studenata koji su pohađali programe medijske pismenosti, i onih koji to nisu, jeste u vezi sa medijskim uticajem na usvajanje rodnih uloga. Naime, studenti koji su u toku obrazovanja medijski opismenjavani svesniji su medijskog uticaja na usvajanje rodnih uloga, dok je kod studenta koji nisu pohađali predmete koji tretiraju medijsku pismenost, izražen visok stepen nesigurnosti. Ovo nedvosmisleno ukazuje na to da iako mladi koji nisu medijski formalno obrazovani percipiraju rodne stereotipe u medijima, i dalje nemaju dovoljno razvijenu kritičku svest, odnosno znanje o moći medija, kada je u pitanju internalizacije poželjnih rodnih identiteta i oblika društvenog delovanja, propagiranih u sredstvima masovnog komuniciranja. 
Imajući u vidu rezultate istraživanja, kao i prethodne studije koje pokazuju da je kratka izloženost medijskoj pismenosti nedovoljna da izazove kontrareakciju dominantnog društvenog pritiska, imperativ odgovornog društva jeste uspostavljanje sistemskog multimedijalnog opismenjavanja, i to u ranom osnovnoškolskom uzrastu, usled zahteva složenog medijskog sistema, koji se kontinuirano razvija, širi, i utiče na konstrukciju stavova, mišljenja, ideala i vrednosti. Sa tim u vezi razvijanje kritičkog odnosa prema sveprisutnim medijskim sadržajima nužno mora postati deo pedagoških praksi.

\section{Literatura}

Bussey, K. \& Bandura, A. (1999). Social cognitive theory of gender development and differentiation. Psychological Review. 106 (4), 676-713.

Gerbner, G. \& Gross, L. (1976). Living With Television: The Violence Profile. Journal of Communilation, 26 (2). The Annenberg School of Communications.

Gerbner, G. Gross, L. Morgan, M. \& Signorielli, N. (1986). "Living with television: The dynamics of the cultivation process". In J. Bryant \& D. Zillman. Perspectives on media effects. Hilldale, NJ: Lawrence Erlbaum Associates. pp. 17-40.

Kellner, D. (1998). Multiple Literacies and Critical Pedagogy in a Multicultural Society. Educational Theory, 48, 103-122.

Ninković - Slavnić, D. (2011). Medijska reprezentacija grupnih identiteta. CM-Časopis za upravljanje komuniciranjem, 19 (6), 15-37.

Nelević, N. (2008). Medijska pismenost i rodna ravnopravnost. U Zbornik radova: Žena u medijskom ogledalu, NVO NOVA Centar za feminističku kulturu, Podgorica, 5-8.

Potter W. J. (2004). Argument for the Need for a Cognitive Theory of Media Literacy. The American Behavioral Scientist, 48 (2), ABI/INFORM Global pg. 266.

Potter, W. J. (2014). A Critical Analysis of Cultivation Theory. Journal of Communication, 64, 1015-1036.

Voojis, M. W. \& van der Voort, T. H. A. (1993). Learning about television violence: The impact of a criticalviewing curriculum on children's attitudinal judgments of crime series. Journal of Research and Development in Education, 26, 133-142.

Vujović, M. (2016). Komparativna analiza reklamne fotografije i reprezentacije roda $u$ socijalističkoj i tranzicijskoj Srbiji, (neobjavljena doktorska disertacija), Univerzitet umetnosti u Beogradu, Beograd

Irving, L. \& Berel, S. R. (2001). Comparison of media-literacy programs to strengthen college women'sresistance to media images. Psychology of Women Quarterly, 5, $103-112$. 


\title{
MEDIA EDUCATION AND PERCEPTION OF GENDER STEREOTYPE IN MEDIA
}

\author{
Tatjana Djukic \\ University of Niš, Faculty of Philosophy, Department of Communication \\ and Journalism, \\ Ph.D. student \\ Dusan Aleksic \\ University of Niš, Faculty of Philosophy, Department of Communication \\ and Journalism
}

\begin{abstract}
In the paper the authors are analyzing the perception of gender stereotypes in the media of students who have attended media literacy programs, and comparing them with students who did not. The aim of the study was to examine whether there is a difference in the perception of gender stereotypes in the media between these two groups of respondents. The method used for data collection was a survey and respondents were students of the University of Nis. The results of the conducted research showed that there is a statistically significant difference in the perception of gender stereotypes in the media among students who attended programs of media literacy and those who did not, only when the internalization of gender stereotypes is considered. The only significant difference between theese two groups of respondents was in agreeing on the media influence in adopting gender roles. Bearing in mind the results of the research, as well as previous studies that show that the short exposure to media literacy is insufficient to cause a counter-reaction of dominant social pressures, it is recommended to establish systemic multimedia literacy in the early elementary school, due to the unstoppable complexing of the information and communication system.
\end{abstract}

Keywords: media education, students, gender, stereotypes, media.

\section{Citiranje članka:}

Đukić, T. i Aleksić, D. (2018). Medijsko obrazovanje i percepcija rodnih stereotipa u medijima. Godišnjak za pedagogiju, 3(1), 77-88. 